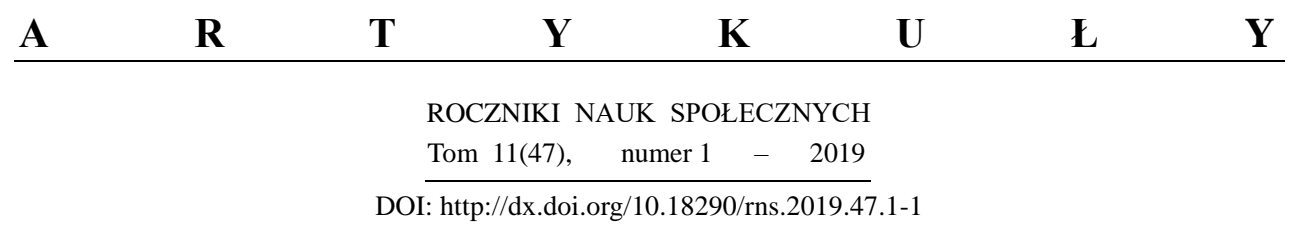

ANDRZEJ GIL

\title{
UCHWAŁA RADY NAJWYŻSZEJ UKRAINY „ПРО ВІДЗНАЧЕННЯ НА ДЕРЖАВНОМУ РІВНІ 75-Х РОКОВИН ПОЧАТКУ ДЕПОРТАЦІЇ УКРАЇНЦІВ” I JEJ ROLA W STOSUNKACH POLSKO-UKRAIŃSKICH
}

WPROWADZENIE

W dniu 8 listopada 2018 roku Rada Najwyższa Ukrainy podjęła uchwałę „Про відзначення на державному рівні 75-х роковин початку депортації українців з Лемківщини, Надсяння, Холмщини, Південного Підляшшя, Любачівщини, Західної Бойківщини у 1944-1951 роках"" (O uczczeniu na poziomie państwowym 75. rocznicy rozpoczęcia deportacji Ukraińców z Łemkowszczyzny, Nadsania, Chełmszczyzny, Południowego Podlasia, Lubaczowszczyzny oraz Zachodniej Bojkowszczyzny w latach 1944-1951). Należy spodziewać się, że realizacja zamierzeń zawartych we wspomnianej uchwale prowadzić będzie do wytworzenia $\mathrm{w}$ społeczeństwie ukraińskim zafałszowanego obrazu wydarzeń związanych z wzajemną wymianą ludności między Rzeczpospolitą Polską a Ukraińską Socjalistyczną Republiką Radziecką na przełomie lat 40. i 50. XX wieku. Prezentowana jest tam bowiem charakterystyczna dla publicznego dyskursu ostatnich lat na Ukrainie interpretacja historii wzajemnych

Dr hab. ANDRZEJ GIL, prof. KUL - Instytut Nauk Politycznych i Spraw Międzynarodowych, Katolicki Uniwersytet Lubelski Jana Pawła II; adres do korespondencji: Al. Racławickie 14, 20-950 Lublin; e-mail: andrzej.gil@iesw.lublin.pl; ORCID iD: https://orcid.org/0000-0002-6415-8339

${ }^{1}$ Постанова Верховної Ради України „Про відзначення на державному рівні 75-х роковин початку депортації украӥнців з Лемківщини, Надсяння, Холмщини, Південного Підляшия, Любачівщини, Західної Бойківщини у 1944-1951 роках”, http://zakon.rada.gov.ua/laws/show/ 2608-viii [dostęp: 20.11.2018]. 
relacji polsko-ukraińskich, którą można scharakteryzować jako zdecydowanie jednostronną i konfrontacyjną.

Poniżej krótkiej analizie zostanie poddanych kilka wątków uchwały, które budzą wątpliwości z punktu widzenia zarówno prawdziwości ich kontekstu historycznego, jak i intencji jej autorów. W tekście dokumentu przywołano nazwy kilku regionów znajdujących się w granicach Polski i związanych z nią w sposób integralny od co najmniej kilkuset lat ${ }^{2}$. Deportowane stamtąd do ZSRR w latach 1944-1951 osoby określono jako: „українців - автохтонних мешканців цих perioнiв”, którzy: „Протягом багатьох століть [...] піддавалися утискам та переслідуванням від колонізаторів за свої віру, мову, землю, зазнавали численних духовних і матеріальних втрат, а в середині XX століття стали жертвами примусового виселення". W takim ujęciu obszary te były więc z gruntu ukraińskie (co zostało podkreślone w dalszej części uchwały), a pod pojęciem „kolonizatorzy” rozumieć należy przede wszystkim Polaków, którzy po dopuszczaniu się nieustannych niegodziwości - ostatecznie deportowali Ukraińców w celu: „призупинення тисячолітнього існування найзахіднішої гілки українства”. Sama uchwała powstała po to, by uczcić: „пам’ять жертв примусової депортації з українських земель”.

Przyjęty przez Radę Najwyższą Ukrainy dokument można traktować jako jedną z wielu prób przywrócenia pamięci o ważnych dla narodu ukraińskiego wydarzeniach, zwłaszcza wobec ich dramatycznego przebiegu i tragicznych skutków, co jest zrozumiałe w obliczu trudności, jakie obecnie przeżywa to państwo. Jednakże zawiera on przy tym takie stwierdzenia i opinie, które nie tylko,

\footnotetext{
${ }^{2}$ Użyte w uchwale nazwy regionów nie odzwierciedlają tradycyjnego nazewnictwa historycznego ziem je niegdyś tworzących, a tym bardziej ich rzeczywistych dziejów, także w kontekście składu etnicznego ich mieszkańców i okoliczności zasiedlenia. Łemkowszczyzna i Zachodnia Bojkowszczyzna to górskie obszary Polski, od ziemi krakowskiej na zachodzie do ziemi sanockiej na wschodzie, ze stosunkowo późnym osadnictwem (koniec XIV-XVI wieku) opartym na substracie wołoskim, później zrutenizowanym w ramach oddziaływania kulturowego Cerkwi prawosławnej i unickiej. Nazwy te zostały wprowadzone do obiegu publicznego dopiero w końcu XIX wieku na fali zapoczątkowania badań etnograficznych w ówczesnej Galicji. Nadsanie to historyczna ziemia przemyska, włączona do Polski w drugiej połowie XIV wieku, natomiast pod pojęciem Lubaczowszczyzny kryje się ziemia bełska, najpierw własność książąt mazowieckich, a od 1462 roku część Korony Królestwa Polskiego. Chełmszczyzna z kolei to w dużym uproszczeniu zachodnia część ziemi chełmskiej, w Polsce od końca XIV wieku. Południowe Podlasie (nazwa ta jest wytworem XIX-wiecznej propagandy rosyjskiej) to zachodnia część ziemi brzeskolitewskiej, stanowiącej część składową Wielkiego Księstwa Litewskiego, a od 1569 roku Korony Polskiej. Nadto i na terenie Łemkowszczyzny, i zachodniej Bojkowszczyzny w XIX i XX wieku reprezentowane były nurty łączące swą tożsamość z projektami narodowo-kulturowymi, innymi niż ukraińskie. Podobnie było na tzw. Chełmszczyźnie i Południowym Podlasiu, których ludność od lat 60. XIX wieku została poddana silnemu oddziaływaniu czynnika rosyjskiego, a po 1905 roku w znacznej części przyjęła polską opcję narodową.
} 
że nie znajdują potwierdzenia w historii, ale i mogą wywołać wrażenie, że jego autorzy nie akceptują obecnego statusu prawnego ziem, o których jest $\mathrm{w}$ nim mowa.

Przesiedlenie byłych obywateli Rzeczypospolitej Polskiej narodowości ukraińskiej do Ukraińskiej SRR odbyło się formalnie na mocy stosownych układów zawieranych między oboma podmiotami, ale faktycznie wynikało $\mathrm{z}$ dwóch przesłanek: sowieckiej praktyki politycznej związanej z deportacjami całych grup społecznych i narodowościowych oraz postanowień zwycięskich mocarstw w kwestii zmian struktury etnicznej w części Europy po II wojnie światowej (i w tej kwestii głos Józefa Stalina wydaje się jednakże decydujący). Warto zatem przyjrzeć się zarówno samemu przebiegowi wysiedleń Ukraińców z Polski po 1944 roku, jak i ich kontekstowi politycznemu, bowiem wydarzenie to wpisywało się w cały ciąg podobnych rozwiązań, stosowanych na kontynencie europejskim w XX wieku.

\section{DEPORTACJE \\ JAKO ELEMENT POLITYKI NARODOWOŚCIOWEJ W ZSRR DO POCZĄTKU LAT 50. XX WIEKU}

Deportacje zarówno grup społecznych, jak i całych narodów (bądź ich znaczących segmentów) w Związku Radzieckim do początku lat 50. XX wieku były wynikiem przyjętych założeń teoretycznych, ustalonych $\mathrm{w}$ toku programowej dyskusji w obozie bolszewickim jeszcze przed rewolucją październikową. Podejście do kwestii narodowościowej i społecznej charakteryzowało się w niej swoistą ambiwalencją, dobrze widoczną w dokumentach programowych i praktyce politycznej leninowskiej frakcji Rosyjskiej Socjaldemokratycznej Partii Robotniczej, zwłaszcza w okresie walki o władzę w 1917 roku. Zakładało ono z jednej strony rozbudzenie niepodległościowych dążeń nierosyjskich narodów na terenie imperium carskiego $\mathrm{w}$ celu jego rozsadzenia od wewnątrz, $\mathrm{z}$ drugiej zaś usuwanie barier na drodze do ponadnarodowego zjednoczenia klasy robotniczej wokół idei rewolucji zgodnie z przyjętą wizją przyszłego społeczeństwa klasowego. Stąd zagadnienie narodowościowe w początkach istnienia bolszewickiej Rosji miało kluczowe znaczenie przy tworzeniu jej struktury wewnętrznej, która po 30 grudnia 1922 roku przybrała postać Związku Socjalistycznych Republik Radzieckich, dodajmy, że z problemem ukraińskim jako jednym $\mathrm{z}$ bardziej newralgicznych ${ }^{3}$.

${ }^{3}$ В. ДЁннингХАУс, В тени «Большого Брата». Западные национальные меньшинства в СССР 1917-1938 г2., Москва 2011, s. 32-54. 
Podstawą prawną do deportacji były postanowienia różnych organów władzy sowieckiej (w tym bezpieczeństwa) oraz stosowne zapisy w kodeksach karnych Rosyjskiej FSRR i republik związkowych. Sama praktyka wysiedlania osób i grup (także etnicznych) stanowiących z punktu widzenia władz zagrożenie ewoluowała wraz z postępem umacniania się pozycji Stalina jako jedynego ośrodka decyzyjnego ${ }^{4}$.

O ile w latach 20. i w początku lat 30. przesiedlano określone grupy społeczne (według oficjalnej nomenklatury klasy nie nadające się do życia w sowieckiej rzeczywistości), w tym chłopów sprzeciwiających się kolektywizacji rolnictwa, o tyle w drugiej połowie tegoż dziesięciolecia rozpoczęły się wywózki osób, wobec których zastosowano kryterium narodowościowe, aż do całych narodów włącznie. Deportacje tego typu trwały aż do śmierci Stalina w 1953 roku i objęły ponad 3600000 osób kilkunastu narodowości ${ }^{5}$.

Ze względów ideologicznych przy przechodzeniu do kolejnych etapów zaostrzenia walki klasowej wygodniejsze i bardziej nośne propagandowo było odejście od abstrakcyjnych kategorii „wrogów ludu”, „trockistów”, „kułaków” czy „szkodników” na rzecz konkretnych i poznawczo uchwytnych pojęć, szybko identyfikowalnych w społeczeństwie sowieckim, zwłaszcza w okresie odejścia od polityki „korenizacji” na rzecz narastania wielkoruskiego szowinizmu. Stąd nacisk na stosowanie w oficjalnej retoryce nazw własnych narodów poddanych represjom, łącznie $\mathrm{z}$ wywózkami $\mathrm{w}$ regiony o bardzo niekorzystnych, wręcz szkodliwych dla egzystencji ludzkiej właściwościach (dodajmy, że pierwszym, tak stygmatyzowanym narodem, byli zamieszkali w ZSRR Polacy, poddani ostrym prześladowaniom w ramach tzw. Operacji Polskiej) ${ }^{6}$.

Przesiedlenia, dokonywane w ZSRR (oraz w państwach tzw. demokracji ludowej, czyli znajdujących się po 1944-1945 roku w orbicie jego wpływów) aż do początku lat 50. XX wieku, w rozumieniu ówczesnych władz były jak najbardziej racjonalne. Ich celem było bądź ukaranie osób lub grup społecznych i etnicznych za działalność sprzeczną z sowieckim prawem (łącznie z ich plano-

${ }^{4}$ S. CIESIELSKI, Masowe deportacje w ZSRR - charakterystyka wybranych aspektów zjawiska, „Dzieje Najnowsze” 33(2001), nr 3, s. 30-36.

${ }^{5}$ Н. БуГАЙ, Что это было?, w: Иосиф Сталин - Лаврентию Берии: «Их надо депортировать». Документы, факты, комментарии, вступ. ст., сост., послесл. Н. Бугай, Москва 1992, s. 3-15; В. БЕРдинских, Спеи̧поселениы. Политическая ссылка народов советской России, Москва 2005, s. 15.

${ }^{6}$ П. Полян, Депортащии и этничность, w: Сталинские депортаици 1928-1953, сост. Н.Л. Поболь, П. Полян, Москва 2005, s. 10-14; П.Э. БлитстЕйн, Национальное строительство лил русификация? Обязательное изучение русского языка в советских нерусских школах, w: Государство наций: Империя и национальное строительство в эпоху Ленина и Сталина, ред. Р. Г. Суни, Т. Мартин, Москва 2011, s. 310-335; Л. Сяньчжун, Плюсы и минусы политики «коренизации» СССР в 1920-е годы, „Ойкумена” 2014, nr 1, s. 41-47. 
wanym unicestwieniem poprzez osiedlenie w skrajnie nieprzyjaznych warunkach geograficzno-klimatycznych bez żadnej pomocy ze strony państwa), prewencja i zapobieganie wszelkim, rzeczywistym czy urojonym zagrożeniom, demograficzne wzmocnienie wyludnionych obszarów lub też zasilenie siłą roboczą poszczególnych działów gospodarki ${ }^{7}$. Takie ruchy ogromnych mas ludności władze sowieckie uważały za naturalne, zwłaszcza w kontekście wydarzeń związanych z II wojną światową i będących jej następstwem dobrowolnych i przymusowych migracji zarówno w zachodniej części ZSRR, jak i w całej Europie Środkowej i Wschodniej, znajdującej się pod okupacją Armii Czerwonej. Stąd deportację Ukraińców z ziem polskich po 1944 roku należy traktować jako jeden z elementów, będących składową ówczesnej sowieckiej polityki (nie tylko narodowościowej) w tej części kontynentu.

\section{DOBROWOLNA I WYMUSZONA WYMIANA LUDNOŚCI W STOSUNKACH DWUSTRONNYCH W EUROPIE W XX WIEKU (WYBRANE PRZYKLADY)}

Dążenie do w miarę jednolitej struktury etnicznej państw leżących w strefie mieszanej etnicznie było zjawiskiem obecnym w dziejach Europy w XX wieku. Zasadniczym celem była tu wzajemna wymiana ludności, dobrowolna lub wymuszona, prowadząca do usunięcia niechcianej mniejszości narodowej i sprowadzenie na jej miejsce rodaków z sąsiedniego państwa, z którym dokonano takiej wymiany. Dobitnym przykładem takich praktyk była wzajemna wymiana ludności, dokonana między Grecją a Turcją na mocy traktatu w Lozannie (24 lipca 1923 roku). W jego wyniku do Grecji przesiedliło się z Azji Mniejszej około 900 000-1 200000 Greków, a z Grecji do Turcji około 400000 Turków ${ }^{8}$.

Na konferencji w Poczdamie (17 lipca-2 sierpnia 1945 roku) przywódcy zwycięskich mocarstw podjęli decyzję o wysiedleniu Niemców z tych terenów Polski (tzw. ziemie zachodnie i północne), które weszły w jej skład mocą postanowień wówczas przyjętych. Podobnie stać się miało z mniejszością niemiecką w Czechosłowacji i na Węgrzech ${ }^{9}$. Jednocześnie na konferencji w Paryżu

\footnotetext{
${ }^{7}$ S. CIESIELSKI, Masowe deportacje w ZSRR - charakterystyka wybranych aspektów zjawiska, s. 40-50; В. БЕрдинских, Спейоселениы. Политическая ссылка народов советской России, s. $55-68$.

${ }^{8}$ E.J. ZÜRCHER, Turcja. Od sułtanatu do wspótczesności, Kraków 2013, s. 161-164.

${ }^{9}$ M.A. BABICKI, Sytuacja mniejszości narodowych $i$ etnicznych $w$ państwach Europy Środkowo-Wschodniej w latach 1989-2004 z punktu widzenia spoleczności międzynarodowej, „Acta Politica”. Zeszyty Naukowe Uniwersytetu Szczecińskiego 2015, nr 34, s. 77-78; A. PAZIK, Migracje przymusowe jako instrument konsolidacji państwa narodowego $w$ XX wieku. Przypadek wysiedleń
} 
(16 lipca-18 października 1946 roku) takąż decyzję podjęto w stosunku do ludności węgierskiej, zamieszkującej dotychczas Słowację, a na jej miejsce zamierzano sprowadzić Słowaków z obszarów Węgier ${ }^{10}$.

Przemieszczenia ludności, mające na celu ujednolicenie struktury narodowej sąsiadujących ze sobą państw w Europie w XX wieku, były stosowaną praktyką, chociaż niemal zawsze miały one charakter wymuszony, a dotknięci tym ludzie przeżywali niezmiernie traumatyczne doświadczenie utraty swojej „małej ojczyzny”.

\section{DEPORTACJA LUDNOŚCI UKRAIŃSKIEJ Z POLSKI PO 1944 ROKU}

Po II wojnie światowej w granicach Rzeczypospolitej Polskiej znalazła się kilkusettysięczna mniejszość ukraińska (około 630 000-700 000 osób), zamieszkująca południowo-wschodnie tereny państwa. Były to następujące powiaty (w całości lub części) w kilku województwach: krakowskim - Nowy Sącz, Nowy Targ; rzeszowskim - Brzozów, Gorlice, Jarosław, Jasło, Krosno, Lesko, Lubaczów, Łańcut, Przemyśl, Przeworsk, Rzeszów, Sanok; lubelskim - Biała Podlaska, Biłgoraj, Chełm, Hrubieszów, Krasnystaw, Kraśnik, Lubartów, Radzyń Podlaski, Tomaszów Lubelski, Włodawa; warszawskim: Łosice, Siedlce, Sokołów Podlaski; białostockim: Bielsk Podlaski, Siemiatycze. Ukraińcy cechowali się stosunkowo dobrze rozwiniętą świadomością narodową, większą w województwach południowych, gdzie przeważał grecki katolicyzm, mniejszą w województwach wschodnich, gdzie dominowało prawosławie.

Traumatycznym przeżyciem dla Polaków i Ukraińców było wyznaczenie granicy między Rzeczpospolitą Polską a Ukraińską Socjalistyczną Republiką Radziecką (porozumienia polsko-radzieckie w sprawie granicy z 27 lipca 1944 roku oraz 16 sierpnia 1945 roku. Granica została skorygowana jeszcze raz, zgodnie z umową z dnia 15 lutego 1951 roku, gdy dokonano wymiany okolic

Niemców z Polski po II wojnie światowej, „Kultura i Polityka”. Zeszyty naukowe Wyższej Szkoły Europejskiej im. ks. Józefa Tischnera w Krakowie 2013, nr 13, s. 139; L. OLEJNIK, Wysiedlenie Niemców z Europy Środkowo-Wschodniej w polityce międzynarodowej (1939-1945). Wybrane problemy. „Si vis pacem, para bellum”. Bezpieczeństwo i polityka Polski: księga jubileuszowa ofiarowana profesorowi Tadeuszowi Dubickiemu, red. R. Majzner, Częstochowa-Włocławek 2013, s. 701-719, ,Zeszyty Historyczne”, t. 12.

${ }^{10}$ R. ZAwISTOWSKa, Demografia i rozmieszczenie ludności węgierskiej w Słowacji 1918-1950, „Studia z Dziejów Rosji i Europy Środkowo-Wschodniej” 46(2011), s. 118-125. 
Bełza na okolice Ustrzyk Dolnych ${ }^{11}$ ). Teoretycznie podstawą była tu tzw. linia Curzona, ale faktycznie przyjęto za odniesienie granicę wypracowaną na mocy porozumienia radziecko-niemieckiego z 28 września 1939 roku. Zauważmy przy tym, że wobec rozległego pogranicza polsko-ukraińskiego, gdzie ludność obu narodowości była przemieszana, nie było możliwe wyznaczenie obiektywnej linii wzajemnego rozgraniczenia, i zawsze po obu stronach jakkolwiek poprowadzonej linii granicznej pozostaliby przedstawiciele drugiego narodu.

Zarówno Ukraińcy, jak i Polacy przebieg nowej granicy przyjęli z niezadowoleniem, z tym że strona polska nie miała żadnych możliwości wpływu na generalne zasady podziału terytorium pogranicznego. Natomiast po stronie sowieckiej istniały w tym okresie różne poglądy na przebieg nowej linii granicznej. Rzecznikiem znacznego przesunięcia na zachód zasięgu Ukraińskiej SRR był Nikita Chruszczow, ówczesny sekretarz Komitetu Centralnego KP (b) Ukrainy. W liście do Stalina z 20 lipca 1944 roku proponował on, by: „Do Radzieckiej Ukrainy [...] przyłączyć następujące rejony: Chełm, Hrubieszów, Zamość, Tomaszów, Jarosław i niektóre inne punkty, przylegające do powyższych rejonów. Można $\mathrm{z}$ tych rejonów utworzyć w składzie USRR obwód chełmski, z obwodowym centrum w Chełmie. Po włączeniu tych rejonów w skład Związku Radzieckiego państwowa granica zostanie wyprostowana, nie będzie zwisał nad Lwowem duży występ w rejonie Sokala. Jeżeli Wy wyrazicie uznanie dla mojej propozycji, to niezwłocznie wezwę potrzebnych ludzi do siebie, do sztabu Frontu, i przystąpię do formowania obwodu chełmskiego i do zagospodarowywania tych rejonów, które wejdą do tego obwodu. Jeśli Wy zgodzicie się z moją propozycją, to przyślę mapę obwodu chełmskiego i projekt granicy państwowej"12.

Nie było zatem przypadkiem, że już w lipcu 1944 roku mieszkańcy niektórych wsi z powiatów chełmskiego, hrubieszowskiego, tomaszowskiego, włodawskiego i zamojskiego, a także nowotarskiego, pozostający w jurysdykcji radzieckiej administracji wojennej, zwrócili się do różnych organów państwowych Ukraińskiej SRR z petycjami o włączenie części województw: lubelskiego, rzeszowskiego i krakowskiego w skład tej republiki ${ }^{13}$. Jednakże wkrótce zmieniły

${ }^{11}$ A.A. WaWryniUK, Granica polsko-sowiecka po 1944 roku (na odcinku z Ukraina), Chełm 2015, s. 128-149, 394-414.

12 Лист секретаря ЦК КП(б)У М. Хрущзова Й. Сталіну про утворення Холмської області в складі УСРР, w: В. СЕРГй̆ук, Етнічні межі і державний кордон Украӥни, Київ 2008, s. $480-481$.

13 Депортації. Західні землі України кіния 30-х - початку 50-х рр. Документи, матеріали, спогади. У трьох томах, т. 2, 1946-1947 рр., упор. Ю. Сливка та ін., Львів 1998, s. 163-165; Ю. Макар, М. Горний, В. Макар, А. Салюк, Від депортачіï до депортачіï. Суспільно-політичне життя холмсько-підляських україниів (1915-1947). Дослідження. Спогади. Документи. У трьох томах, т. 1, Дослідження, Чернівці 2011, s. 583-589. 
się plany polityczne sowieckiego kierownictwa co do przyszłego statusu Polski (22 lipca 1944 roku ujawniono istnienie Polskiego Komitetu Wyzwolenia Narodowego właśnie w Chełmie) i już w sierpniu 1944 roku władze Ukraińskiej SRR rozpoczęły przygotowania do przyjęcia na jej teren przesiedleńców narodowości ukraińskiej zza Sanu i Bugu.

Nie ulega wątpliwości, że decyzja o deportacji obywateli polskich narodowości ukraińskiej do Ukraińskiej SRR zapadła wśród kierowniczego gremium sowieckiego. Jak wspomniano, w dniu 9 września 1944 roku utworzony z inicjatywy Stalina i będący całkowicie pod jego kontrolą PKWN zawarł umowę z rządem radzieckiej Ukrainy o przesiedleniu ludności polskiej z Ukraińskiej SRR do Polski i ukraińskiej z Polski do Ukraińskiej SRR ${ }^{14}$. Analogiczna umowa tego samego dnia została podpisana z Białoruską SRR, a 22 września z Litewską SRR. Zarówno umowa o granicy, jak i umowa o wzajemnych przesiedleniach wynikała z decyzji władz radzieckich i była realizacją ich koncepcji i wyobrażeń politycznych. Sądzić można, że organa sowieckie czyniły w tej materii pewne rozpoznanie nastrojów wśród Ukraińców po zachodniej stronie Bugu, bowiem, jak sprawozdawał Ławrientij Beria kierownictwu sowieckiemu (Stalin, Mołotow i Malenkow), zapewne w początku drugiej połowy 1944 roku: „Według NKWD ZSRR większa część ukraińskiej ludności żyjącej na polskim terytorium życzliwie odnosi się do przewidzianego przesiedlenia do Ukraińskiej SRR"

Przeświadczenie, że działacze skupieni wokół Związku Patriotów Polskich, z których wywodziły się późniejsze kadry przejmujące władzę na zajmowanych przez Armię Czerwoną ziemiach na zachód od Bugu, od początku dążyli do budowy państwa jednonarodowego, dominuje w literaturze ${ }^{16}$. Stanowisko takie nie bierze pod uwagę pełnego podporządkowania organów nowej komunistycznej władzy w Polsce interesom sowieckim. Władza ta nie mogła definiować się w kategorii interesów narodowych, bowiem wówczas nie pełniłaby tej funkcji, do której została powołana. Wszelkie zatem deklaracje ideowe, także o przyszłym kształcie narodowościowym Rzeczypospolitej, wynikały z zamierzeń taktycznych, częstokroć bardzo doraźnych, związanych z potrzebą chwili i obliczo-

${ }^{14}$ Repatriacja czy deportacja. Przesiedlenie Ukraińców z Polski do USRR 1944-1946, t. 1, Dokumenty 1944-1945, red. E. Misiło, Warszawa 1996, dok. 8, s. 30-38.

${ }^{15}$ Иосиф Сталин - Лаврентию Берии: «Их надо депортировать». Документы, факты,, комментарии, s. 176.

16 R. Drozd, Polityka władz wobec ludności ukraińskiej w Polsce w latach 1944-1989, Warszawa 2001, s. 28-29; K. PRZYBYsz, Polska myśl polityczna 1939-1945. Zarys problematyki, Warszawa 2000, s. 108; P. EBERHARDT, Polska granica wschodnia 1939-1945, Warszawa 1995, s. 144-145; E. Mironowicz, Polityka władz Polski Ludowej wobec Ukraińców w latach 1944-1947, w: Akcja „,Wista”, red. J. Pisuliński, Warszawa 2003, s. 55-56; J. PISULIŃsKi, Przesiedlenie ludności ukraińskiej z Polski do USRR w latach 1944-1947, Rzeszów 2017, s. 65-67. 
ne były na użytek wewnętrzny i międzynarodowy. Celem nowej władzy była bowiem pełna sowietyzacja Polski, dokonana w oparciu o potencjał militarny ZSRR $^{17}$.

Deportacja, zwana w umowie ewakuacją, teoretycznie miała mieć charakter dobrowolny. Ludność rolnicza na terenie Ukraińskiej SRR mogła albo przystąpić do kołchozów, albo otrzymać dział ziemi, nie większy jednak niż 15 ha. Rozpoczęcie ewakuacji miało nastąpić 1 października 1944 roku, a zakończyć 1 lutego następnego roku. Terminy te były prolongowane, i ostatecznie deportację zakończono faktycznie do lutego $1947 \mathrm{roku}$, a formalnie podpisaniem stosownego układu w dniu 6 maja tegoż roku. Osoby decydujące się na wyjazd miały otrzymać szereg ulg doraźnych, np. zwolnienia z dostaw przymusowych i podatków oraz mogły wywieźć określony w układzie dobytek. Przewóz wszystkich wyjeżdżających gwarantował rząd Ukraińskiej SRR. Zorganizowano ponadto całą strukturę deportacji, tj. określono kwestie pełnomocników i przedstawicieli każdej ze stron i organizacji wyjazdów, łącznie z punktami przekraczania granicy i wzorami odpowiednich dokumentów.

W pierwszej fazie działania dokonano rejestracji wszystkich osób narodowości ukraińskiej i rusińskiej. 15 października 1944 roku zaczęły wyjeżdżać pierwsze transporty z Polski do USRR. Do końca tego roku wyjechało około 20000 osób, w ogromnej większości dobrowolnie. Jednakże w początku 1945 roku zaczęło brakować chętnych na wyjazd, bowiem w swej podstawowej masie ludność ukraińska nie chciała opuszczać ziemi, którą uważała za swoją małą ojczyznę. Ponadto w tym okresie zaczęły powracać osoby lub całe rodziny, które wyjechały wcześniej. Ich opowieści skutecznie odstraszały ewentualnych chętnych do dobrowolnego wyjazdu ${ }^{18}$. W połowie 1945 roku akcja wysiedleńcza uległa w zasadzie załamaniu.

W tej sytuacji władze polskie podjęły decyzję o zastosowaniu różnych form przymusu, łącznie z użyciem wojska, milicji i organów bezpieczeństwa, używanych m.in. do pacyfikacji wsi ukraińskich. Wobec ludności ukraińskiej zastosowano na szeroką skalę terror, połączony z eksterminacją poszczególnych osób, rodzin i całych miejscowości. Do tych akcji włączała się niekiedy okoliczna ludność polska, a nawet poszczególne oddziały zbrojnej opozycji antykomunistycznej. Akcje te wywołały przeciwdziałanie Ukraińskiej Powstańczej Armii, co

\footnotetext{
17 Por. J. Wrona, Stosunki polsko-radzieckie $w$ latach 1944-1945 i ich ukraińskie aspekty, w: Pogranicze. Studia z dziejów stosunków polsko-ukraińskich wXX wieku, red. Z. Mańkowski, Lublin 1992, s. 89-95.

18 О. САВчук, Свої серед свої. Депортаиії украӥнців з Холмщчини й Підляшия в 1944-1947 pp., Луцьк 2012, s. 107-125.
} 
doprowadziło do eskalacji działań zbrojnych i aktów terroru wobec ludności cywilnej obu stron konfliktu ${ }^{19}$.

Oficjalne skutki deportacji przedstawiają suche liczby i zestawienia. Wynika z nich, że od 15 października do lutego 1947 roku z Polski do USRR wyjechało ponad 482000 osób (szacunki radzieckie są tu minimalnie niedokładne) podlegających układowi między Ukraińską SRR a Polską z 9 września 1944 roku, a wśród nich 459135 Ukraińców, 28846 Rosjan, 126 Białorusinów, 13789 Rusinów i 243 osoby innej narodowości. Jednocześnie na teren Białoruskiej SRR (zgodnie z układem Polski z tą republiką z tego samego dnia) wywieziono z Polski dodatkowo 5894 Ukraińców $^{20}$. Szacuje się wszakże, że na terenie Polski pozostało jeszcze około 150 000-200 000 osób narodowości ukraińskiej, z których część (około 140 000) wywieziono w ramach akcji „Wisła”, ale pewien odsetek pozostał w pasie nadbużańskim w województwach warszawskim i białostockim.

Deportowani pozostawili w swojej dawnej ojczyźnie majątek, wyceniany w 1947 roku na 735278993 rubli, ziemię i lasy o powierzchni 461317 ha oraz różnego rodzaju inne dobra, zdane na granicy przy wyjeździe i wycenione na sumę 17000000 złotych. Ziemia i wszelkie nieruchomości zostały przejęte na własność państwa zgodnie z dekretem z dnia 5 września 1947 roku. Państwo przejęło także mienie różnorakich organizacji ukraińskich, w tym Cerkwi greckokatolickiej. W ten sposób z krajobrazu kulturowego południowo-wschodniej Polski znikł ważny i istotny komponent, tworzący przez wieki tradycję Rzeczypospolitej.

\section{WNIOSKI}

Przyjęta przez Radę Najwyższą Ukrainy uchwała „Про відзначення на державному рівні 75-х роковин початку депортації українців" jest dokumentem, którego pojawienie się $\mathrm{w}$ przestrzeni publicznej należy interpretować

19 Р. Дрозд, Полсько-украйнськи відносини на Холмщзині, Надсянні та Лемківщчині в 19441947 рр., w: Волинь і Холмщина 1938-1947. Полсько-украӥнське протистояння та його відлуння. Дослідження, документи, спогади [Украӥна. Культурна спадщина, національна свідомість, державність, 2003/10], ред. Я. Ісаєвич, Львів 2003, s. 341-347; R. DROZD, Ukraińcy w Polsce 1944-1947 - losy, postawy, nastroje, w: Akcja ,,Wisła”, s. 64-74; С. Заброварний, Депортачії 1944-1946... За кремлівським взірием - викореніти до дна, „Український альманах 2004”, Варшава 2004, s. 219-223.

20 Депортації. Західні землі України, т. 2, s. 175; Teczka specjalna J. W. Stalina. Raporty NKWD z Polski 1944-1946, opr. zb., Warszawa 1998, s. 543-545; Repatriacja czy deportacja. Przesiedlenie Ukraińców z Polski do USRR 1944-1946, t. 2, Dokumenty 1946, red. E. Misiło, Warszawa 1999, załącznik nr 7, s. 358-360 (wielkość zbiorcza: 483499 osób); J. PISULIŃSKI, Przesiedlenie ludności ukraińskiej, s. 540. 
jako element strategii Kijowa, której celem jest konsolidacja społeczeństwa ukraińskiego wokół obozu władzy poprzez odwołanie się do emocji opartych na odczuciu historycznych krzywd i niesprawiedliwości, których między innymi skutkiem jest obecna, trudna i złożona, sytuacja państwa. Przywołanie bardzo nośnego pojęcia „narodu-ofiary” jawi się więc jako zabieg mający na celu odwrócenie uwagi od rzeczywistych problemów związanych z indolencją obozu władzy poprzez zaistnienie tematu zastępczego, jakim jest deportacja Ukraińców z ziem polskich w latach 1944-1951.

Wydarzenie to, niejednorodne przecież, było jednym $\mathrm{z}$ elementów stalinowskiej polityki narodowościowej, realizowanej od końca lat 30. XX wieku jako ważny czynnik konstruujący ogólną sytuację państwa sowieckiego. Ponadto wpisywało się w ciąg tego typu zdarzeń, przyjętych przez europejskie i światowe czynniki polityczne jako narzędzie do rozwiązywania potencjalnych konfliktów narodowościowych. Twórcy uchwały nadali wysiedleniom ludności ukraińskiej z Polski po 1944 roku wyjątkowy charakter, abstrahując od obopólnego przecież dramatu Ukraińców i Polaków wypędzanych ze swoich „małych ojczyzn” po obu stronach granicy w ramach sowieckiej polityki deportacji. Nadto jako akcję wysiedleńczą potraktowano narzuconą przez władze sowieckie korektę granicy z 1951 roku, która była dla strony polskiej skrajnie niekorzystna i dotknęła w tym samym stopniu Ukraińców, jak i Polaków.

Trudno przy tym uznać, że strona polska, wobec jej ubezwłasnowolnienia, miała jakikolwiek wpływ na samą decyzję o wysiedleniach. Stąd obecna w uchwale niewątpliwie antypolska retoryka nie nawiązuje do konkretnej rzeczywistości historycznej, a jest raczej projekcją wizji jej twórców na temat postrzegania przez nich dziejów ludności ukraińskiej i za taką uważanej na południowo-wschodnich obszarach współczesnej Polski. Zarówno użyta terminologia, jak i opis sytuacji tejże ludności należy uznać nie tylko za ahistoryczny, ale i za negatywnie wpływający na stan obecnych stosunków ukraińsko-polskich. Jeśli uznamy tę uchwałę za element polityki historycznej państwa ukraińskiego, to trzeba przyjąć, że poprzez - jak się wydaje, świadome - zniekształcenie dziejowego kontekstu i przyjętą argumentację, polityka taka oparta jest na silnych antypolskich resentymentach, co może prowadzić do przyszłych, różnorakich w swej naturze, roszczeń. 


\section{BIBLIOGRAFIA}

BABICKI M.A., Sytuacja mniejszości narodowych i etnicznych w państwach Europy ŚrodkowoWschodniej w latach 1989-2004 z punktu widzenia społeczności międzynarodowej, „Acta Politica". Zeszyty Naukowe Uniwersytetu Szczecińskiego 2015, nr 34.

CIESIELSKI S., Masowe deportacje w ZSRR - charakterystyka wybranych aspektów zjawiska, „Dzieje Najnowsze” 33(2001), nr 3.

DrozD R., Polityka władz wobec ludności ukraińskiej w Polsce w latach 1944-1989, Warszawa 2001.

DrozD R., Ukraińcy w Polsce 1944-1947 - losy, postawy, nastroje, w: Akcja „Wisła”, red. J. Pisuliński, Warszawa 2003.

EBERHARDT P., Polska granica wschodnia 1939-1945, Warszawa 1995.

Mironowicz E., Polityka władz Polski Ludowej wobec Ukraińców w latach 1944-1947, w: Akcja „Wisła”, red. J. Pisuliński, Warszawa 2003.

OLEJNIK L., Wysiedlenie Niemców z Europy Środkowo-Wschodniej w polityce międzynarodowej (1939-1945). Wybrane problemy. „Si vis pacem, para bellum”. Bezpieczeństwo i polityka Polski: księga jubileuszowa ofiarowana profesorowi Tadeuszowi Dubickiemu, red. R. Majzner, Częstochowa-Włocławek 2013. „Zeszyty Historyczne”, t. 12.

PAZIK A., Migracje przymusowe jako instrument konsolidacji państwa narodowego w XX wieku. Przypadek wysiedleń Niemców z Polski po II wojnie światowej, „Kultura i Polityka”. Zeszyty naukowe Wyższej Szkoły Europejskiej im. ks. Józefa Tischnera w Krakowie 2013, nr 13.

PISUliŃSKi J., Przesiedlenie ludności ukraińskiej z Polski do USRR w latach 1944-1947, Rzeszów 2017.

PRZYBYSZ K., Polska myśl polityczna 1939-1945. Zarys problematyki, Warszawa 2000.

Repatriacja czy deportacja. Przesiedlenie Ukraińców z Polski do USRR 1944-1946, t. 1, Dokumenty 1944-1945, red. E. Misiło, Warszawa 1996.

Repatriacja czy deportacja. Przesiedlenie Ukraińców z Polski do USRR 1944-1946, t. 2, Dokumenty 1946, red. E. Misiło, Warszawa 1999.

Teczka specjalna J. W. Stalina. Raporty NKWD z Polski 1944-1946, opr. zb., Warszawa 1998.

WAWRYNIUK A.A., Granica polsko-sowiecka po 1944 roku (na odcinku z Ukrainą), Chełm 2015.

Wrona J., Stosunki polsko-radzieckie w latach 1944-1945 i ich ukraińskie aspekty, w: Pogranicze. Studia z dziejów stosunków polsko-ukraińskich w XX wieku, red. Z. Mańkowski, Lublin 1992.

ZAWISTOWSKA R., Demografia i rozmieszczenie ludności węgierskiej w Słowacji 1918-1950, „Studia z Dziejów Rosji i Europy Środkowo-Wschodniej” 46(2011).

ZÜRCHER E. J., Turcja. Od sułtanatu do współczesności, Kraków 2013.

БЕРдинских В., Спецпоселенцы. Политическая ссылка народов советской России, Москва 2005 .

БлитстЕйн П. Э., Национальное строительство лил русификация? Обязательное изучение русского языка в советских нерусских школах, w: Государство наций: Империя и национальное строительство в эпоху Ленина и Сталина, ред. Р. Г. Суни, Т. Мартин, Москва 2011.

ДённингХАУС В., В тени «Большого Брата». Западные национальные меньшинства в СССР 1917-1938 гг., Москва 2011.

ДЕПортАції. Західні землі України кінця 30-х - початку 50-х рр. Документи, матеріали, спогади. У трьох томах, т. 2, 1946-1947 рр., упор. Ю. Сливка та ін., Львів 1998.

ДрОзд Р., Полсько-українськи відносини на Холмщині, Надсянні та Лемківщині в 1944-1947 pp., w: Волинь і Холмщина 1938-1947. Полсько-українське протистояння та його від- 
луння. Дослідження, документи, спогади, [=Україна. Культурна спадщина, національна свідомість, державність, 2003/10], ред. Я. Ісаєвич, Львів 2003.

ЗАБРовАРний С., Депортації 1944-1946... За кремлівським взірцем - викореніти до дна, „Український альманах 2004”, Варшава 2004.

Иосиф Сталин - Лаврентию Берии: «Их надо депортировать». Документы, факты, комментарии, вступ. ст., сост., послесл. Н. Бугай, Москва 1992.

МАКАР Ю., ГОРНИЙ М., МАКАР В., САЛЮК А., Від депортації до депортації. Суспільнополітичне життя холмсько-підляських українців (1915-1947). Дослідження. Спогади. Документи. У трьох томах, т. 1, Дослідження, Чернівці 2011.

Полян П., Депортации и этничность, w: Сталинские депортации 1928-1953, сост. Н.Л. ПоБоль, П. Полян, Москва 2005.

САвчук О., Свої серед своїх. Депортації українців з Холмщини й Підляшшя в 1944-1947 pp., Луцьк 2012.

Сергійчук В., Етнічні межі і державний кордон України, Київ 2008.

Сяньчжун Л., Плюсы и минусы политики «коренизации» СССР в 1920-е годы, „Ойкумена” 2014, nr 1.

\author{
UCHWAŁA RADY NAJWYŻSZEJ UKRAINY \\ „ПРО ВІДЗНАЧЕННЯ НА ДЕРЖАВНОМУ РІВНІ \\ 75-Х РОКОВИН ПОЧАТКУ ДЕПОРТАЦІЇ УКРАЇНЦІВ" \\ I JEJ ROLA W STOSUNKACH POLSKO-UKRAIŃSKICH
}

Streszczenie

Artykuł przedstawia okoliczności związane z uchwaleniem przez Radę Najwyższą Ukrainy dekretu o obchodzeniu 75. rocznicy zapoczątkowania deportacji Ukraińców z Polski po II wojnie światowej. Prezentuje także uwarunkowania samej deportacji, a także możliwe skutki realizacji tej uchwały. Autor wyraża przypuszczenie, że dyskusja wokół uchwały, a przede wszystkim samej deportacji, wpłynie negatywnie na współczesne stosunki ukraińsko-polskie.

Słowa kluczowe: deportacje; stosunki ukraińsko-polskie; polityka historyczna.

\section{RESOLUTION OF THE HIGHEST COUNCIL OF UKRAINE „ПРО ВІДЗНАЧЕННЯ НА ДЕРЖАВНОМУ РІВНІ 75-Х РОКОВИН ПОЧАТКУ ДЕПОРТАЦІЇ УКРАЇНЦІВ" AND ITS ROLE IN POLISH-UKRAINIAN RELATIONS}

$$
\text { S u m m a r y }
$$

The article presents the circumstances related to the passing of a decree by the Verkhovna Rada of Ukraine on celebrating the 75th anniversary of the initiation of the deportation of Ukrainians from Poland after World War II. It also presents the conditions of the deportation itself, as well as the possible effects of implementing this resolution. The author speculates that the discussion around the resolution, and above all the deportation itself, will negatively affect contemporary Ukrainian-Polish relations.

Key words: deportations; Ukrainian-Polish relations; historical policy. 


\section{ANEKS}

\section{Постанова Верховної Ради України}

Про відзначення на державному рівні 75-х роковин початку депортації українців з Лемківщини, Надсяння, Холмщини, Південного Підляшшя, Любачівщини, Західної Бойківщини у 1944-1951 роках

У 2019 році виповнюється 75 років від початку депортації з Лемківщини, Надсяння, Холмщини, Південного Підляшшя, Любачівщини, Західної Бойківщини у 1944-1951 роках українців-автохтонних мешканців цих регіонів.

Протягом багатьох століть українці на цих територіях піддавалися утискам та переслідуванням від колонізаторів за свої віру, мову, землю, зазнавали численних духовних і матеріальних втрат, а в середині XX століття стали жертвами примусового виселення.

Процес депортації українців у 1944-1951 роках мав форму військових операцій проти мирного населення, супроводжувався грубим порушенням основоположних прав і свобод людини і громадянина, повною забороною повернення на рідні землі, вилученням майна, безальтернативним закріпленням за новими місцями поселення, залишати які було заборонено, обмеженням політичних, соціальних, економічних і культурних прав, що призвело до руйнування української культурної та історичної спадщини, поставило під загрозу знищення низку етнографічних груп українського народу. Депортація мала на меті призупинення тисячолітнього існування найзахіднішої гілки українства.

Вшановуючи пам'ять жертв примусової депортації з українських земель, враховуючи шкоду, яку їм завдали комуністичні режими, що призвело до знищення національної ідентичності та культури, з метою відновлення історичної справедливості та інформування суспільства про процес примусового виселення українців 3 Лемківщини, Надсяння, Холмщини, Південного Підляшшя, Любачівщини, Західної Бойківщини у 1944-1951 роках Верховна Рада України постановляє:

1. У 2019 році відзначити на державному рівні 75-ті роковини початку депортації українців з Лемківщини, Надсяння, Холмщини, Південного Підляшшя, Любачівщини, Західної Бойківщини у 1944-1951 роках.

2. Установити в Україні День пам'яті українців - жертв примусового виселення 3 Лемківщини, Надсяння, Холмщини, Південного Підляшшя, Любачівщини, Західної Бойківщини у 1944-1951 роках, який відзначати щороку у другу неділю вересня.

3. Рекомендувати Президенту України оголосити в Україні 2019 рік Роком Пам'яті депортованих українців з Лемківщини, Надсяння, Холмщини, Південного Підляшшя, Любачівщини, Західної Бойківщини у 1944-1951 роках.

4. Рекомендувати Кабінету Міністрів України:

1) забезпечити відзначення у 2019 році на державному рівні 75-х роковин початку депортації українців з Лемківщини, Надсяння, Холмщини, Південного Підляшшя, Любачівщини, Західної Бойківщини у 1944-1951 роках;

2) у місячний строк 3 дня прийняття цієї Постанови утворити організаційний комітет, розробити та затвердити план заходів з відзначення 75-х роковин початку депортації українців з Лемківщини, Надсяння, Холмщини, Південного Підляшшя, Любачівщини, Західної Бойківщини у 1944-1951 роках. 
5. Рекомендувати Міністерству освіти і науки України:

1) забезпечити проведення у закладах середньої та вищої освіти уроків, семінарів, круглих столів, науково-практичних конференцій, інших тематичних заходів 3 метою збереження історичної пам'яті про депортацію українців 3 Лемківщини, Надсяння, Холмщини, Південного Підляшшя, Любачівщини, Західної Бойківщини у 1944-1951 роках;

2) запропонувати закладам середньої та вищої освіти передбачити у навчальних планах вивчення історичних подій, що стосуються депортації українців з Лемківщини, Надсяння, Холмщини, Південного Підляшшя, Любачівщини, Західної Бойківщини у 1944-1951 роках.

6. Рекомендувати Міністерству культури України забезпечити організацію у закладах культури тематичних виставок, експозицій, присвячених 75 -м роковинам початку депортації українців з Лемківщини, Надсяння, Холмщини, Південного Підляшшя, Любачівщини, Західної Бойківщини у 1944-1951 роках.

7. Рекомендувати Державному комітету телебачення і радіомовлення України організувати тематичні теле- і радіопередачі, присвячені подіям, що відбувалися на території Лемківщини, Надсяння, Холмщини, Південного Підляшшя, Любачівщини, Західної Бойківщини у 1944-1951 роках, та сприяти висвітленню державними засобами масової інформації заходів у зв'язку з 75-ми роковинами початку депортації українців з Лемківщини, Надсяння, Холмщини, Південного Підляшшя, Любачівщини, Західної Бойківщини у 1944-1951 роках.

8. Контроль за виконанням цієї Постанови покласти на Комітет Верховної Ради України з питань культури і духовності.

9. Ця Постанова набирає чинності з дня iї прийняття.

Голова Верховної Ради Украӥни А.[ндрій] Парубій

м. Киї

8 листопада 2018 року

№ 2608-VIII

Źródło: http://zakon.rada.gov.ua/laws/show/2608-viii 